\title{
HOUSING PREFERENCES IN VARIOUS STAGES OF THE HUMAN LIFE CYCLE
}

\author{
Sławomir Palicki \\ Department of Investment and Real Estate \\ Poznań University of Economics and Business \\ e-mail:Slawomir.Palicki@ue.poznan.pl
}

\begin{abstract}
Customer preferences on the real estate market have been a topic of scientific research for decades. Recently, a lot of attention has been given to the issue of housing attitudes and needs of chosen groups of buyers. Among them, a particular increase in interest in real estate meeting the needs of the elderly and young buyers has been observed. However, Polish literature lacks a holistic analysis of consumer preferences through their entire lives.

The article recognizes the phenomenon of the changing preferences of potential real estate buyers depending on their current stage of life. All the age groups for a representative quota sample of Poznan citizens were asked to assess the importance of real estate cost factors. This allowed the housing attitudes of potential participants of the real estate market to be reconstructed in view of the changes in their adult lives. The conclusions drawn from the research might be useful for both academic discourse, and for practical application on the real estate market.
\end{abstract}

Key words: housing market, residential market, housing preferences, human life cycle.

JEL Classification: I38, R2, R31.

Citation: Palicki, S. (2020). Housing preferences in various stages of human life cycle. Real Estate Management and Valuation, 28(1), 91-99.

DOI: https:// doi.org/10.2478/remav-2020-0008

\section{Introduction}

Housing preferences are an interesting matter from the point of view of researchers and people involved in the real estate market. There are a lot of publications regarding the satisfaction, preferences and needs of customers on the real estate market, including those targeting chosen age groups - usually seniors or younger buyers. However, the issue of cost factor assessment during the person's entire lifecycle has not been researched properly.

The research thesis that the set of preferences of potential real estate customers depends on the customers' age, and changes together with their lifecycle has been formulated for this article. The main goal of the publication is to present the results of a previously realized survey. Among the specific aims of research are:

- evaluating the creation and the stability/changeability of real estate preferences regarding different cost factors in various stages of life,

- establishing potential tendencies when it comes to the changeability of cost factor importance over the course of one's lifecycle,

- pointing to some attributes being more stable than others, and attempting to explain the reason behind this phenomenon,

- verifying whether more important cost factors are characterized by a higher stability in one's preferences set throughout the entire lifecycle.

It needs to be emphasized that the researched phenomena are not to be confused with:

- the matter of human needs when it comes to flat characteristics, 
- an attempt to establish a standard set of housing needs (as an alleged "best" set of preferences, the "ideal type"),

- potential housing attitudes of people

- an evaluation of the desired comfort, or a reflection of the minimal level of accepted comfort behind the analyzed attributes of flats.

The undertaken research fits into the analysis of the intensity of perceiving particular human needs in relation to housing, which is reflected in the evaluation of the importance of its particular features through the development of a potential customer's life. The article focuses on an attempt to answer the following question: which features of flats, and to what extent, are important to people at different stages of their lives? The intention of the author was not to evaluate the "correctness" of human beliefs, but only to reconstruct and objectively assess the level of their stability and the potential direction of their evolution thorough the entire lifecycle. It is difficult to point to an objective need "model" or the ideal type. It is much more accurate, from the research point of view, to recognize their shape and changes over time. It must be emphasized that the data shown in the article do not show the acceptable level of quality regarding a given feature, but the hierarchy of their importance to the respondents. The research was conducted using Paper \& Pen Personal Interview (PAPI), in Poznan, 2015.

\section{Literature review}

The development of the housing estate market and its clear division into particular segments (flats for senior citizens, for the young, or the premium sector) requires more detailed research. The area is quite complex and complicated when it comes to the phenomena themselves, but also to the access to information. Another obstacle is the high cost of research, starting from the design stage, through the actual research stage, to the presentation of results. However, there is no doubt that there are many subjects which might be greatly interested this area of housing market research.

Modern science provides researches with numerous methods and tools for researching the real estate market (Gawron, 2009). Most of them are based on the quantitative approach - rather fixed mathematical and statistical rules (Batóg \& Foryś, 2011; Foryś, 2011). The qualitative approach which uses projective methods such as focus groups or in-depth interviews has become increasingly popular in the recent years.

Analyses of the preferences, needs, motivations and attitudes of buyers are among the areas which are important in housing market research, both from the cognitive point of view as well as in terms of practical application. Thanks to early elaborations on the matter, researchers from well-developed countries paid attention to the aforementioned areas and their importance (Nelson \& Rabianski, 1988). First market experiments inspired Polish researchers as well - numerous attempts to recognize and model customer preferences can be observed. Various methods were used to do so, often adapted from the marketing area (Bartłomowicz, 2002; Gawron, 2012; Olejnik, 2013). Foryś and Kokot (2012) pointed to the possibility of using the measurement of potential customer preferences in real estate valuation. A lot of interesting concepts concerning particular groups of customers were created, such as single-family households from rural areas, the inhabitants of new housing estates, or students (Ahn \& Lee, 2016; Lepkova, Butkiene\& Bełej, 2016; Źróbek-Różańska \& Szulc 2018).

The tendency to deepen the specialization of considerations led to the search for determinants of changes inf the real estate buyers' preferences and decisions. One might find research related to economic factors (Abeysinghe \& Gu, 2011), or cultural and social ones (Costa, Oliveira \& Hochheim, 2001; Jabareen, 2005; Roe, Irwin \& Morrow-Jones, 2005). Preferences are also shaped by external factors, e.g. changes connected with work, the financial situation of the family, the establishment or breakup of a family (Dieleman, 2001). Some researches demonstrate how the moving desires of both partners in couples influence the decision-making process about household relocation (Coulter, Ham \& Feijten 2012). Recent publications contend that residential mobility should be interpreted as relational practices that link lives through time and space while connecting people to structural conditions (Coulter, Ham \& Findlay, 2016). Research areas regarding housing for elderly people are gradually becoming more emphasized due to the needs of aging societies from Western Europe. The necessity to reconstruct the needs of senior citizens led to a growing number of such analyses (Mandič, 2016; Yu \& Lee, 2017; Strączkowski \& Boruta, 2018).

The drive to study and understand the motivations and determinants of human activity on the real estate market, throughout a person's entire life, can finally be observed (Yang, 2009; Attanasio et al., 
2012; Aydilek, 2013). Several concepts trying to explain the changes in people's housing preferences have been formulated. Among them, it is definitely worth mentioning the housing ladder theory. It points to the need for gradual promotion, or the improvement of housing conditions when making decisions regarding subsequent purchases. There have also been detailed studies on factors disturbing the housing ladder theory (Morrow-Jones \& Menning, 2005; Halket \&, Santhanagopalan, 2014). Another interesting matter in the research of human preferences is the concept of a life cycle - or the relationship between a person's age and changing attitudes and needs in regards to housing (MorrowJones \& Menning, 2005; Barrios, Colom \& Moles, 2013; Marekwica, Schaefer \& Sebastian, 2013). A cognitive gap can be seen in this area regarding the housing market in Poland.

\section{Data and methods}

The survey was conducted in Poznan, on a group of 2537 people, between the 18th August and 6th October, 2015. Thereby, the survey took approximately 1\% of housing buildings in the city, which made for complete randomness of the research (addresses to be found in the sampling frame). The selection of respondents for research was carried out by the Poznan branch of Statistics Poland, using a randomly constructed survey (it was not made available to the author of this publication). The task of Statistics Poland was to ensure the representativeness of research in the field of several features of respondents, including age. Questions were prepared by a team of experts on social policy, community housing and public space on the basis of a focus interview with Poznan inhabitants. The questionnaire was first consulted with the scientific community and the city hall, and then tested on a small group before staring the actual survey. The research was conducted using PAPI - personal visits paid by interviewers at respondents' flats or houses.

The research gathered information regarding the evaluation of cost factors regarding flats which the respondents would be willing to buy. 10 attributes were taken into consideration: the technical condition of the flat, technical condition of the building, heating, technology, location, size of the flat, functionality of the flat, brightness of rooms, attractiveness of views and appearance of the building. The respondents were to evaluate the importance of given attribute on a 1-10 scale ( 1 standing for the lowest value and 10 for the highest). Only adults took part in the study. The interviewees were divided into six age groups which reflected different life situations at each stage:

- 18-24 (the period of education),

- 25-29 (the beginning of a professional career and the time of taking first independent housing decisions on the real estate market),

- 30-44 (the period of high professional engagement and family development)

- 45-59 (the period of stability, the immobile productive age),

- 60-69 (the end of professional activity),

- 70 and more (senior citizens).

\section{Empirical results}

The results of the research have been aggregated in Table 1. Average evaluations of factors given by the respondents at different stages of their lives have been illustrated. They were complemented by averages and standard deviations calculated for the evaluation of factors for all the age groups, and also for all the attributes for different age groups of Poznan inhabitants.

The importance of features of flats (by age groups of respondents)

Table 1

\begin{tabular}{|c|c|c|c|c|c|c|c|c|}
\hline \multirow[t]{2}{*}{ Flat features } & \multicolumn{6}{|c|}{ Age groups of respondents } & \multirow{2}{*}{$\begin{array}{c}\text { Average } \\
\text { (all life) }\end{array}$} & \multirow{2}{*}{$\begin{array}{c}\text { Standard } \\
\text { deviation of } \\
\text { evaluation } \\
\text { (all life) }\end{array}$} \\
\hline & $\begin{array}{c}\text { up to } \\
24\end{array}$ & $25-29$ & $30-44$ & $45-59$ & $60-69$ & $\begin{array}{c}70 \text { and } \\
\text { more }\end{array}$ & & \\
\hline $\begin{array}{c}\text { Technical } \\
\text { condition of the } \\
\text { flat }\end{array}$ & 8.80 & 8.58 & 8.87 & 8.97 & 9.17 & 8.95 & 8.89 & 0.20 \\
\hline $\begin{array}{c}\text { Technical } \\
\text { condition of the } \\
\text { building }\end{array}$ & 8.35 & 8.55 & 8.93 & 9.04 & 9.07 & 8.81 & 8.79 & 0.29 \\
\hline Heating & 8.29 & 8.53 & 8.76 & 9.02 & 9.05 & 8.89 & 8.76 & 0.30 \\
\hline
\end{tabular}




\begin{tabular}{ccccccccc}
\hline Technology & 8.03 & 8.54 & 8.83 & 8.93 & 8.95 & 8.56 & 8.64 & 0.35 \\
\hline Location & 8.48 & 8.53 & 8.61 & 8.73 & 8.79 & 8.55 & 8.62 & 0.12 \\
\hline Size of the flat & 8.20 & 8.39 & 8.72 & 8.48 & 8.54 & 8.38 & 8.45 & 0.18 \\
\hline $\begin{array}{c}\text { Functionality of } \\
\text { the flat }\end{array}$ & 7.91 & 8.29 & 8.58 & 8.64 & 8.66 & 8.36 & 8.41 & 0.29 \\
\hline $\begin{array}{c}\text { Brightness of } \\
\text { rooms }\end{array}$ & 7.60 & 8.04 & 8.34 & 8.83 & 8.98 & 8.52 & 8.38 & 0.51 \\
\hline $\begin{array}{c}\text { Attractiveness of } \\
\text { views }\end{array}$ & 6.85 & 7.17 & 7.70 & 8.19 & 8.44 & 8.05 & 7.73 & 0.62 \\
\hline $\begin{array}{c}\text { The appearance } \\
\text { of the building }\end{array}$ & 7.04 & 7.38 & 7.79 & 8.11 & 8.14 & 7.83 & 7.72 & 0.43 \\
\hline $\begin{array}{c}\text { Average (all } \\
\text { features) }\end{array}$ & 7.95 & 8.20 & 8.51 & 8.70 & 8.78 & 8.49 & 8.44 & 0.31 \\
\hline $\begin{array}{c}\text { Standard } \\
\text { deviation (all } \\
\text { features) }\end{array}$ & 0.62 & 0.52 & 0.44 & 0.34 & 0.33 & 0.36 & - & - \\
\hline
\end{tabular}

Source: own study.

The basic conclusion which can be drawn from the preferences analysis of potential flat buyers in Poznan is the general high evaluation of the importance of factors (Table 1). Among all the researched age groups, individual results ranged from 6.85 to 9.17 (scale 1-10). The phenomenon is even more visible when considering the average results for the respondents' entire life cycle (the average from results in age categories), which produced differences in results ranging from 7.72 for the "the appearance of the building," up to 8.89 for "the technical condition of the flat". It is worth adding that 8 out of 10 factors were evaluated, on average, above 8 points. The inhabitants of Poznan mostly value the technical characteristics (8.64 - 8.89 points), including heating and the technology. The next important factor was the location (8.62), followed by the size of the flat, its functionality and attractiveness $(7.72-8.45)$.

The standard deviation for the factor importance among different age groups points to the scale of dispersion. The technical features of the flat (technical condition of both the flat and the building), and the parameters which are strongly related with the housing market (location, size, functionality) proved to be relatively stable when it comes to their importance throughout the entire lifecycle of potential buyers. The deviation value ranged from 0.12 to 0.35 . Such factors are seen to be wellestablished and stable during the different periods of one's life. The factors regarding the aesthetics and subjective assessments (the brightness of rooms, the attractiveness of views, the appearance of a building) proved to be more changeable - between 0.43 and 0.62 . The evaluation of the importance of such factors proves to be subject to the highest fluctuation during a person's life.

When it comes to the importance of flat features for different age groups, an interesting tendency needs to be pointed out: the importance evaluation of the aforementioned features grows steadily, starting from the early adulthood (18-24) up to the end of professional activity (60-69), and then the numbers fall significantly for senior citizens (over 70). The values given by the respondents aged $30-44$ are the closest to the average. The inhabitants of Poznan, with time, generally give a lot of attention to particular flat features, they simply start to care more. However, the process continues up to some point in time. The phenomenon is reversed after turning 70 - senior citizens are less interested in real estate features, or even become indifferent to them. Housing preferences of the elderly are less distinctive, not as pronounced as they used to be in previous stages of their lives. What is important, the drop of interest in flat features was quite significant when compared to the results of people aged 60-69 (0.3 - 0.4 for most of the features). The scores for heating and the size of the flat did not fall as significantly (0.16). Generally, it may be stated that during the last stage of life, the hierarchy of preferences is rather similar to the set of people aged 30-44.

It is worth having a look at standard deviations calculated for all the flat features. It turns out that the importance evaluation of particular features differs most among the youngest (the standard deviation for the age group 18-24 was 0.62); the differentiation level then decreases significantly, together with lifecycle development (for people older than 45 , the deviation was only 0.36 at its peak) All in all, throughout the entire lifecycle development, there are two overlapping tendencies: 
- the increase of feature evaluation (people care more about the analyzed features, pay more attention to them),

- lower differences in evaluation (the results for particular features become more and more similar, the levels of importance regarding features seem to be more similar to one another).

For senior citizens (aged 70 and more), a decrease in the importance levels has been observed, together with a slight increase in the differentiation of feature evaluation.

Table 2

Ranking of the importance of a flat's features (by age groups of respondents)

\begin{tabular}{ccccccc}
\hline Flat features & \multicolumn{7}{c}{ Age groups of respondents } \\
\cline { 2 - 7 } & up to 24 & $25-29$ & $30-44$ & $45-59$ & $60-69$ & $\begin{array}{c}70 \text { and } \\
\text { more }\end{array}$ \\
\hline Technical condition of the flat & 1 & 1 & 2 & 3 & 1 & 1 \\
\hline Technical condition of the building & 3 & 2 & 1 & 1 & 2 & 3 \\
\hline Heating & 4 & 4 & 4 & 2 & 3 & 2 \\
\hline Technology & 6 & 3 & 3 & 4 & 5 & 4 \\
\hline Location & 2 & 4 & 6 & 6 & 6 & 5 \\
\hline Size of the flat & 5 & 6 & 5 & 8 & 8 & 7 \\
\hline Functionality of the flat & 7 & 7 & 7 & 7 & 7 & 8 \\
\hline Brightness of rooms & 8 & 8 & 8 & 5 & 4 & 6 \\
\hline Attractiveness of views & 10 & 10 & 10 & 9 & 9 & 9 \\
\hline The appearance of the building & 9 & 9 & 9 & 10 & 10 & 10 \\
\hline
\end{tabular}

Source: own study.

Table 2 presents the importance rankings of particular flat features, taking into consideration the average scores for different age groups from Table 1. Rankings should be read in columns, separately for each age group. For example, among the youngest people (age group "up to 24"), the feature "location" falls in second place, which means it is the second most important feature after the "technical condition of the flat". Less important for this age group is the "attractiveness of views". The advantage of such a way of presenting results is its transparency and the fact that it is easy to interpret. Apart from this, it is possible to follow the ranking position of each feature, which reflects its importance throughout the entire lifecycle of people, with this being particularly desirable from the point of view of this article. The smallest differences in ranking positions (changing merely one position throughout the entire life) were obtained by the functionality of the flat, the attractiveness of views and the appearance of the building. These features proved to be less important for the respondents. Interestingly, the change in the ranking for features described as very important, such as the technical condition of a building or heating, was also not very significant - up to two positions in the whole lifecycle. The fluctuation level for the remaining features was rather high - even up to a change of 3-4 ranking positions. The very low-ranking position of location proved to be rather surprising, as people over 30 evaluated it as not very important. Only the young (aged 18-24) evaluated this feature as the second most important on the entire list. It needs to be emphasized that in point-based evaluation (Table 1), location behaved in a stable manner. There are also two features the importance of which increases together with the respondents' age, i.e.: heating and brightness.

Table 3

Ranking of age groups of respondents (by evaluation of the importance of a flat's features)

\begin{tabular}{ccccccc}
\hline \multirow{2}{*}{ Flat features } & \multicolumn{7}{c}{ Age groups of respondents } \\
\cline { 2 - 8 } & up to 24 & $25-29$ & $30-44$ & $45-59$ & $60-69$ & $\begin{array}{c}70 \text { and } \\
\text { more }\end{array}$ \\
\hline Technical condition of the flat & 5 & 6 & 4 & 2 & 1 & 3 \\
\hline Technical condition of the building & 6 & 5 & 3 & 2 & 1 & 4 \\
\hline Heating & 6 & 5 & 4 & 2 & 1 & 3 \\
\hline Technology & 6 & 5 & 3 & 2 & 1 & 4 \\
\hline
\end{tabular}




\begin{tabular}{cllllll}
\hline Location & 6 & 5 & 3 & 2 & 1 & 4 \\
\hline Size of the flat & 6 & 4 & 1 & 3 & 2 & 5 \\
\hline Functionality of the flat & 6 & 5 & 3 & 2 & 1 & 4 \\
\hline Brightness of rooms & 6 & 5 & 4 & 2 & 1 & 3 \\
\hline Attractiveness of views & 6 & 5 & 4 & 2 & 1 & 3 \\
\hline The look of the building & 6 & 5 & 3 & 2 & 1 & 4 \\
\hline
\end{tabular}

Source: own study.

Table 3 illustrates the age group ranking of the respondents when it comes to their evaluation of the features' importance. Rankings should be read in rows separately for each flat feature. For example, the feature "technical condition of the flat" gains the highest importance among people at age of 60-69 (position 1 in the ranking showed in the first row of Table 3). The lowest importance to this feature is connected with people aged 25-29. It allows for a clear (clearer than in Table 1) reconstruction of the way in which the importance of flat features is seen by different age groups. It turns out that the greatest attention was drawn to almost every attribute by the 60-69 age group. The second group, almost equally sensitive to flat features, were people aged 45-59. Senior citizens (70 and more), and respondents aged 30-44 see these features in a similar way, the only difference being the evaluation of the size of the flat, which is the most important feature for the younger group, whereas senior citizens do not see it as particularly important. Respondents below 30 proved to express the lowest importance of the analyzed features.

In order to enrich the analysis of the studied phenomena, the Kruskal-Wallis relevance test (Aczel, 2005) was used to measure the differences between the average importance of flat features obtained in the age groups of respondents. Comparison of the distribution of these ratings depending on the flats features indicated a statistically relevant difference $(p=0.0019)$. The value of $\mathrm{H}(5, \mathrm{~N}=60)=19.0741$ gave grounds for rejecting the statistical hypothesis about the same distributions of the dependent variable (i.e. importance of flat features) in the analyzed age groups of Poznan residents.

Table 4

Results of post-hoc analysis for the Kruskal-Wallis relevance test (by age groups of respondents)

\begin{tabular}{|c|c|c|c|c|c|c|}
\hline \multirow{2}{*}{$\begin{array}{l}\text { Dependent } \\
\text { variable: } \\
\text { Flat features' } \\
\text { importance }\end{array}$} & \multicolumn{6}{|c|}{$\begin{array}{l}\text { "p" value for multiple comparisons } \\
\text { Independent variable: Age group }\end{array}$} \\
\hline & up to 24 & $25-29$ & $30-44$ & $45-59$ & $60-69$ & 70 and more \\
\hline up to 24 & & 1.000000 & 0.307174 & $0.021480^{*}$ & $0.003948^{*}$ & 0.729542 \\
\hline $25-29$ & 1.000000 & & 1.000000 & 0.296877 & 0.078769 & 1.000000 \\
\hline $30-44$ & 0.307174 & 1.000000 & & 1.000000 & 1.000000 & 1.000000 \\
\hline $45-59$ & $0.021480^{*}$ & 0.296877 & 1.000000 & & 1.000000 & 1.000000 \\
\hline $60-69$ & $0.003948^{*}$ & 0.078769 & 1.000000 & 1.000000 & & 1.000000 \\
\hline 70 and more & 0.729542 & 1.000000 & 1.000000 & 1.000000 & 1.000000 & \\
\hline
\end{tabular}

Source: own study (calculated in Statistica).

The post-hoc analysis for the Kruskal-Wallis test (Table 4) shows that statistically relevant differences in the importance of flat features occurred between the following age groups:

- "up to 24 " and " $45-59$ ",

- "up to 24 " and "60-69".

The importance of features of flats is assessed differently by the group of youngest people (aged up to 24 ) than by the " $45-59$ " and "60-69" age groups (Fig. 1).

\section{Discussion and conclusions}

In the course of the research, it has been observed that sets of preferences of potential real estate customers in Poznan depend on their age and are subject to change with their lifecycle.

Among important conclusions drawn from the research were:

- the fact that interest in flat features increases with age - on the 18 - 69 time scale, 
- potential buyers significantly decrease their evaluation of the features' importance once they have turned 70,

- the most significant increase of feature evaluation occurs when the age group changes from 2529 to $30-44$, and from 18-24 to 25-29,

- potential customers who have turned 45 up to the senior age seem to have the most stable evaluation of feature importance,

- the youngest people taking part in the research (18-24) tend to show the biggest differences when it comes to their evaluation of flat features,

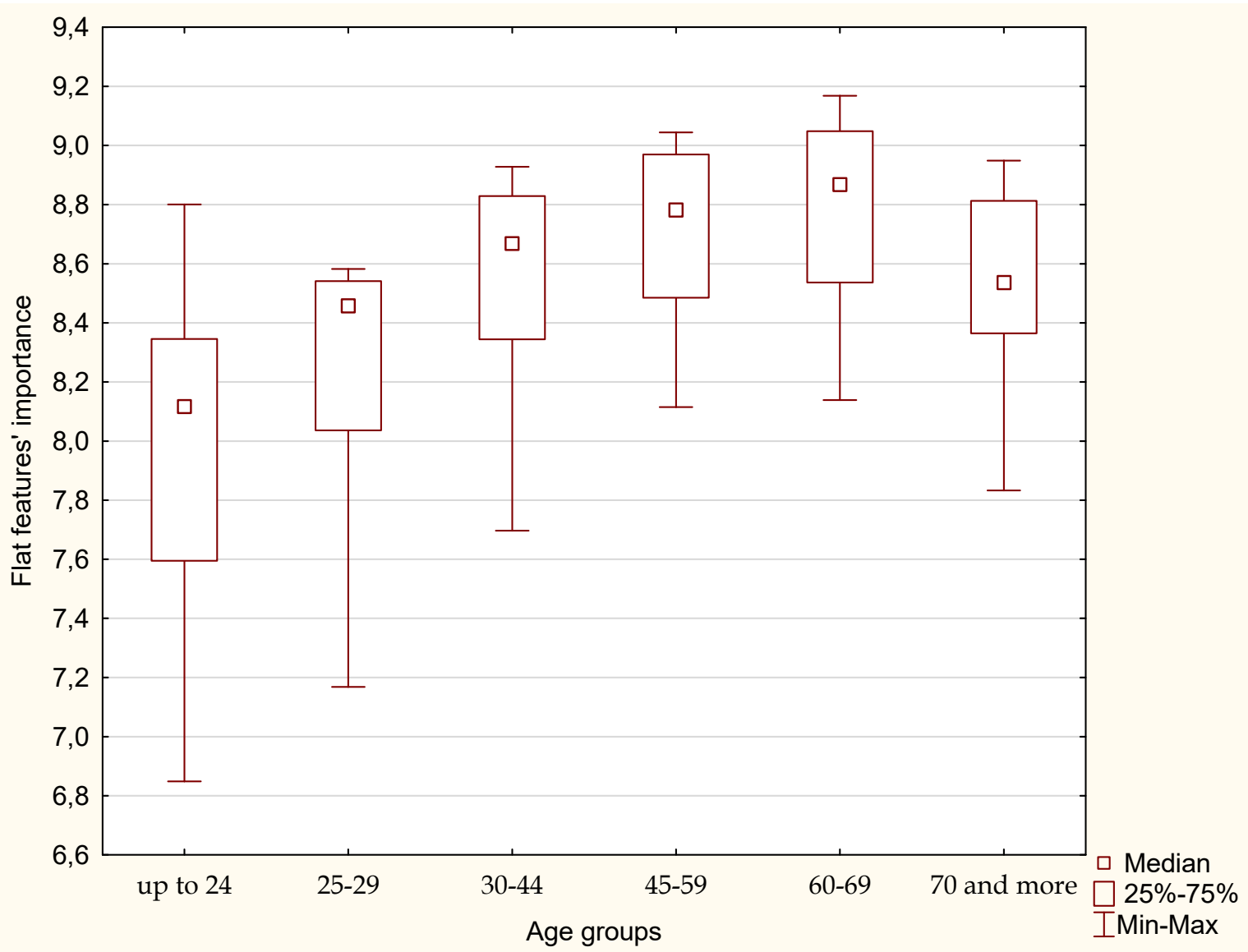

Fig. 1. Flat features' importance by age groups of respondents. Source: own study.

- the most important features throughout the entire lifestyle are the technical condition of the flat, the condition of the building and heating,

- the least important features throughout the entire lifestyle are the functionality of the flat, the attractiveness of views, and the appearance of the building,

- the importance of heating and the brightness of rooms tend to increase together with the lifecycle,

- the features which proved to be the most stable are the functionality of the flat, the attractiveness of views, and the appearance of a building,

- the most stable features when it comes to the evaluation of their importance proved to be the most and the least important features in the hierarchy.

In order to transform all the presented observations to an understandable formula, it can be said that the young do not pay much attention to the features of a flat on the whole, but that they do see particular features as more important than others. Older people tend to focus on the features of a flat, but do not differentiate between their importance, viewing all the features as equally important. An exception to the rule are senior citizens whose interest in all of a flat's features then to drop dramatically, with features being viewed as less important than by people aged 45-69.

Such research results are of particular importance to real estate market practitioners, i.e. developers, investors, property valuators or real estate agents. The younger market participants are 
less sensitive to the strengths and weaknesses of an offered flat, but it will be easier to catch their interest if the features most important to them (such as the condition of the flat or its location) are well adjusted. Young buyers assess flats offered to them in a more selective and less coherent manner. More mature buyers need to become interested in a wide range of flat features since all of them are equally important. Their way of assessing market offers will be more inquisitive, balanced and coherent. Senior citizens seem to be the most difficult group when it comes to assessing market features of flats as their interest in them becomes dramatically decreased in comparison with younger customers.

In the light of the results from Poznan, it seems that people, while gaining more and more experience, gradually give more attention to features of flats, only to later make assessments with lower attention in the last part of their lifecycle.

The research results obtained are worth referring to the basic, most clearly emerging reactions of buyers of flats in Poznan. Certainly, a strong attachment of younger buyers to the technical characteristics of apartments and the advantages of their location is confirmed. Fulfilling their expectations regarding critically important features is enough reason to make a decision to buy a flat. In the case of buyers in the phase of well-developed professional activity and the decline of this activity, we can talk about more comprehensive needs and higher expectations in relation to the purchased flats. It seems that the extensive life experience of these clients justifies their caution and more established needs when it comes to the housing market.

\section{References}

Abeysinghe, T., \& Gu, J. (2011). Lifetime income and housing affordability in Singapore. Urban Studies (Edinburgh, Scotland), 48(9), 1875-1891. https:/ / doi.org/10.1177/0042098010380956.

Aczel, A. D. (2005). Statystyka w zarzadzaniu (Statistics in management). Wydawnictwo Naukowe PWN.

Ahn, M., \& Lee, S.-J. (2016). Housing satisfaction of older (55+) single person householders in U.S. rural communities. Journal of Applied Gerontology, 35(8), 878-911. https:// doi.org/10.1177/0733464815577142 PMID:25846383.

Attanasio, O. P., Bottazzi, R., Low, H. W., Nesheim, L., \& Wakefield, M. (2012). Modelling the demand for housing over the life cycle. Review of Economic Dynamics, 15(1), 1-18. https://doi.org/10.1016/j.red.2011.09.001.

Aydilek, A. (2013). Habit formation and housing over the life cycle. Economic Modelling, 33, 858-866. https:/ / doi.org/10.1016/j.econmod.2013.05.012.

Barrios, V., Colom, M. C., \& Moles, M. C. (2013). Life cycle and housing decisions: A comparison by age cohorts. Applied Economics, 45(32), 4556-4568. https:/ / doi.org/10.1080/00036846.2013.795276

Bartłomowicz, T. (2002). Zastosowanie metody conjoint analysis do pomiaru preferencji potencjalnych nabywców nieruchomości (Application of the conjoint analysis method to measure preferences of potential real estate buyers), Klasyfikacja i analiza danych - teoria i zastosowania (Classification and data analysis - theory and applications). Prace Naukowe Akademii Ekonomicznej we Wroctawiu. Taksonomia, 942(9), 272-280.

Batóg, B., \& Foryś, I. (2011). Modele logitowe w analizie transakcji na warszawskim rynku mieszkaniowym (Logit models in the analysis of transactions on the Warsaw housing market). Studia i Materiaty TNN, 19(3), 34-48.

Costa, J. A., Oliveira, R., \& Hochheim, N. (2001). Applictaion of family life cycle concept in determining potential segment for housing projects: Case study of two downtown projects in Florianopolis, Brasil. Property Management, 20(5), 312-325.

Coulter, R., van Ham, M., \& Feijten, P. (2012). Partner (dis)agreement on moving desires and the subsequent moving behaviour of couples. Population Space and Place, 18, 16-30. https://doi.org/10.1002/psp.700.

Coulter, R., van Ham, M., \& Findlay, A. M. (2016). Re-thinking residential mobility: Linking lives through time and space. Progress in Human Geography, 40(3), 352-374. https:/ / doi.org/10.1177/0309132515575417 PMID:27330243.

Dieleman, F. M. (2001). Modelling residential mobility: A review of recent trends in research. Journal of Housing and the Built Environment, 16, 249-265. https:/ /doi.org/10.1023/ A:1012515709292. 
Foryś, I. (2011). Spoteczno-gospodarcze determinanty rozwoju rynku mieszkaniowego w Polsce (Socioeconomic determinants of development of real estate market in Poland). Wydawnictwo Uniwersytetu Szczecińskiego.

Foryś, I., Kokot, S. (2008). Preferencje potencjalnych nabywców w określaniu wag cech rynkowych nieruchomości (Potential Buyers' Preferences in Defining of Real Estates Market Attributes). Studia i Materiaty Towarzystwa Naukowego Nieruchomości, 16(2), 45-61.

$\mathrm{Fu}, \mathrm{Q}$. (2016). The persistence of power despite the changing meaning of homeownership: An ageperiodcohort analysis of urban housing tenure in China, 1989-2011. Urban Studies (Edinburgh, Scotland), 53(6), 1225-1243. https:// doi.org/10.1177/0042098015571240.

Gawron, H. (2009). Analiza rynku nieruchomości. Wydawnictwo Uniwersytetu Ekonomicznego w Poznaniu.

Gawron, H. (2012). Ewolucja funkcji mieszkania i preferencji klientów na rynku mieszkaniowym (Evolution of Dwelling Functions and Clients' Preferences on the Housing Market), [in:] Trojanek M., Strączkowski L., Z prac Katedry Inwestycji i Nieruchomości. Aktualne problemy rynku nieruchomości w Polsce (From the work of the Department of Investment and Real Estate: Current problems of the real estate market in Poland), Zeszyt naukowy, 231, Wydawnictwo Uniwersytetu Ekonomicznego w Poznaniu, Poznan, 8-18.

Halket, J., \& Santhanagopalan, V. (2014). Saving up or settling down: Home ownership over the life cycle. Review of Economic Dynamics, 17(2), 345-366. https:/ / doi.org/10.1016/j.red.2013.06.002.

Jabareen, Y. (2005). Culture and housing preferences in a developing city. Environment and Behavior, 37(1), 134-146. https:// doi.org/10.1177/0013916504267640.

Lepkova, N., Butkiene, E., \& Bełej, M. (2016). Study of customer satisfaction with living conditions in new apartment buildings. Real Estate Management and Valuation, 24(3), 52-70. https://doi.org/10.1515/remav-2016-0021.

Mandič, S. (2016). Housing for care: A response to the post-transitional old-age gap? Journal of European Social Policy, 26(2), 155-167. https://doi.org/10.1177/0958928716637140.

Marekwica, M., Schaefer, A., \& Sebastian, S. (2013). Life cycle asset allocation in the presence of housing and tax-deferred investing. Journal of Economic Dynamics \& Control, 37(6), 1110-1125. https://doi.org/10.1016/j.jedc.2013.01.008.

Morrow-Jones, H. A., \& Menning, M. V. (2005). The housing ladder, the housing life-cycle and the housing life-course: Upward and downward movement among repeat home-buyers in a US metropolitan housing market. Urban Studies (Edinburgh, Scotland), 42(10), 1739-1754. https://doi.org/10.1080/00420980500231647.

Nelson, T. R., \& Rabianski, J. (1988). Consumer preferences in housing market analysis: An application of multidimensional scaling techniques. AREUEA Journal, 16(2), 138-159. https://doi.org/10.1111/1540-6229.00451.

Olejnik, I. (2013). Badania preferencji klientów na rynku nieruchomości (Clients' Preferences Survey on Real Estates Market) [in:] Trojanek M. (ed.), Ekonomiczne uwarunkowania decyzji na rynku nieruchomości. Wybrane problemy (Economic Conditions of Decisions on the Real Estate Market. Selected Topics), Wydawnictwo Uniwersytetu Ekonomicznego w Poznaniu, pp. 200-201.

Roe, B., Irwin, E. G., \& Morrow-Jones, H. A. (2005). Changes in homeowner preferences for housing density following 11 September 2001. Applied Economics Letters, 12(2), 73-78. https:// doi.org/10.1080/1350485042000307134.

Strączkowski, Ł., \& Boruta, M. (2018). Warunki i decyzje mieszkaniowe seniorów na lokalnym rynku nieruchomości (Seniors' housing conditions and their decisions on the local housing market). Zeszyty Naukowe Uniwersytetu Ekonomicznego w Krakowie, 3(975), 69-81. https:// doi.org/10.15678/ZNUEK.2018.0975.0305.

Yang, F. (2009). Consumption over the life cycle: How different is housing? Review of Economic Dynamics, 12(3), 423-443. https:/ / doi.org/10.1016/j.red.2008.06.002.

$\mathrm{Yu}, \mathrm{C} .$, \& Lee, Y. (2017). Housing requirements for an ageing society. Indoor and Built Environment, 26(4), 441-446. https://doi.org/10.1177/1420326X17704285.

Źróbek-Różańska, A., \& Szulc, L. (2018). Over a million student tenants in Poland: Analysis of preferences. Real Estate Management and Valuation, 26(2), 104-113. https://doi.org/10.2478/remav2018-0020. 